\title{
Interleukin 32 Measurement
}

National Cancer Institute

\section{Source}

National Cancer Institute. Interleukin 32 Measurement. NCI Thesaurus. Code C74830.

The determination of the amount of interleukin 32 present in a sample. 